\title{
Manufacturing Error Conditions Causing Cogging Torque Occurring in Stator in Permanent Magnet Motors
}

\author{
Akihiro Daikoku Member (Mitsubishi Electric Corporation) \\ Masatsugu Nakano Member (Mitsubishi Electric Corporation) \\ Shinichi Yamaguchi Member (Mitsubishi Electric Corporation) \\ Yukari Toide Member (Mitsubishi Electric Corporation) \\ Haruyuki Kometani Member (Mitsubishi Electric Corporation)
}

Keywords: PM motor, cogging torque, manufacturing error, asymmetry, pole/slot ratio, permeance distribution

In this paper we study the condition that the cogging torque caused by manufacturing errors occurs in surface-mounted permanent magnet synchronous motors (SPMSM). Manufacturing errors mean the difference between the ideal condition at the motor design phase and the actual condition in mass production. In particular, errors can be classified into the distortion of the magnetic core, the degradation of magnetic properties, the lack of uniformity of the permanent magnets, etc. In this paper we examine manufacturing errors that occur in stator. They are expressed as the asymmetric spatial distribution of permeance, that is, the component of the spatial distribution function whose number of spatial pulsations $N$ is not equal to the multiple of the stator slot number $Z_{s t}$. In this case the cogging torque component, which has $k \cdot p$ times pulsations per revolution, has generation possibilities, where $p$ is the number of poles and $k$ is a positive integer. We derive the fulfillment requirements for the spatial pulsation number (= spatial mode) $N$ of the asymmetric permeance distribution; that is, $N$ should fulfill one of the three relational expressions as follows:

$$
N=k \cdot p, \quad N= \pm 2 k \cdot p-i_{1} \cdot Z_{s t}, \text { or } N=i_{1} \cdot Z_{s t} \pm 2 k \cdot p,
$$

where $i_{1}$ is a nonnegative integer.

From the relational expressions shown above, we presume that the relationship between the manufacturing errors and the cogging torque characteristics is ruled by the ratio of the number of poles and the number of slots (= pole/slot ratio). In this paper, we concretely show the relationship between the permeance spatial distribution and the cogging torque pulsation number to seven typical motor specifications, each of which has a different pole/slot ratio. The pole/slot ratios are $2: 3,4: 3,8: 9,10: 9,5: 6,1: 3$, and $2: 9$. Furthermore, we discuss the features of the cogging torque component generated for the seven kinds of motors mentioned above.

In order to validate the relational expressions shown above, we conducted a numerical simulation using finite element analysis. Fig. 1 shows the cross-section of two of the seven verification motors; one has 8 poles and 12 slots drawn as (a), and the other has 8 poles and 9 slots drawn as (b). The pole/slot ratios are $2: 3$ and $8: 9$ respectively. Distortions are added to the inner surface of the stator magnetic core cylinder as a manufacturing error factor. The spatial pulsation number of the distortion may be any of 1 to 15 and the distortion amplitude is set to $5 \%$ of the air-gap. Fig. 2 shows an example of FEM calculation results, which indicates the cogging torque components analyzed by DFT. Three cases are analyzed; the first is not distorted, the second has distortion of spatial mode $N=4$, and the third has distortion of spatial mode $N=8$.
Different cogging torque components can be observed according to the motor specifications or the spatial mode of distortion. The same kind of analysis was performed on each of seven motors and the results closely agreed with the results calculated by the relational expressions shown above.

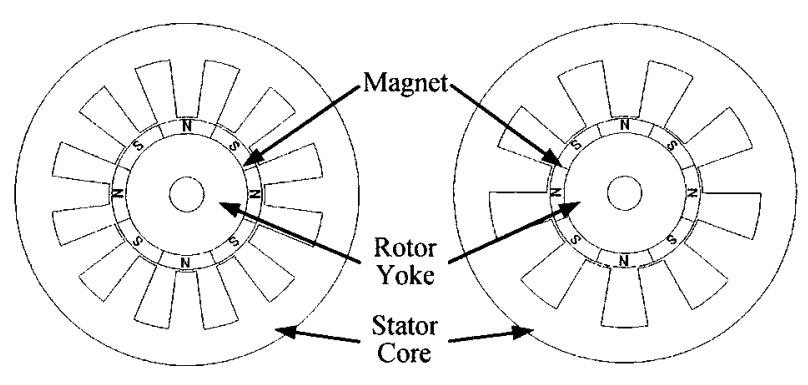

(a) 8 pole 12 slot model

(b) 8 pole 9 slot model

Fig. 1. Cross section of the verification motor
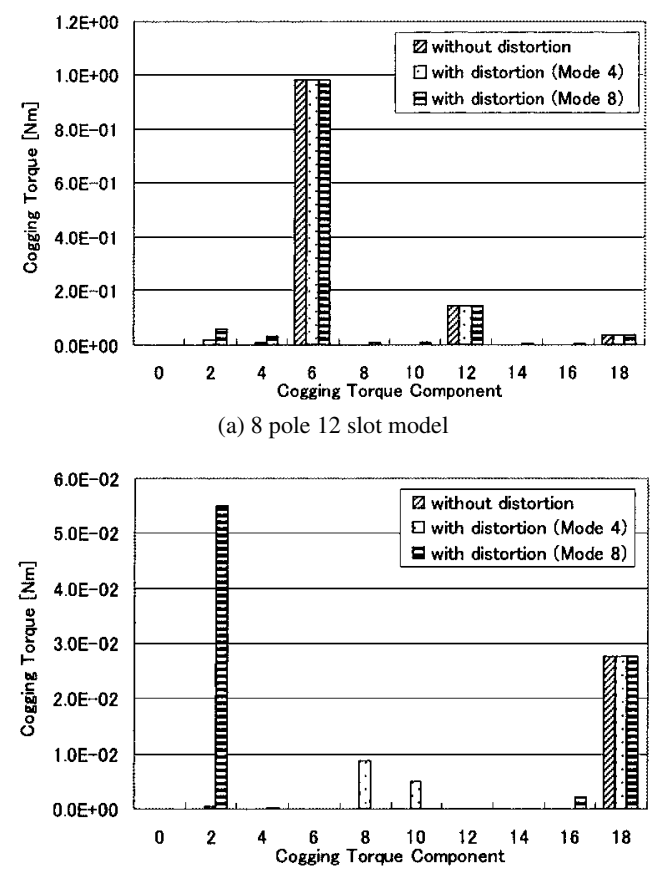

(b) 8 pole 9 slot model

Fig. 2. Analyzed results of cogging torque with/without distortion 


\title{
PMモータの固定子製造誤差に起因する コギングトルクの発生条件
}

\author{
正員 大穀 晃裕* 正員 中野 正嗣* \\ 正員 山口 信一* 正 員 都出結花利* \\ 正員 米谷 晴之*
}

\section{Manufacturing Error Conditions Causing Cogging Torque Occurring in Stator in Permanent Magnet Motors}

\author{
Akihiro Daikoku*, Member, Masatsugu Nakano*, Member, Shinichi Yamaguchi*, Member, \\ Yukari Toide*, Member, Haruyuki Kometani*, Member
}

\begin{abstract}
In this paper we study the condition that the cogging torque occurs, that is caused by manufacturing errors in the stator of PM motors. Manufacturing errors can be classified into the distortion of the magnetic core, the degradation of magnetic properties etc. They are expressed as the asymmetric spatial distribution of permeance, that is, the component of the spatial distribution function whose number of spatial pulsations is not equal to the multiple of the stator slot number. The overviews of this paper are as follows. (1) We derive the relational expression between the spatial pulsation number of the asymmetric component of the permeance distribution function and the pulsation number of cogging torque per revolution. (2) Examples are shown for seven typical motor specifications, each of which has different pole/slot ratio. (3) We conduct finite element analysis for the seven typical motors. The stator cores were distorted and the spatial order of distortion was set to the parameter. The analyzed pulsation number of cogging torque agreed well with the theoretical solutions.
\end{abstract}

キーワード：PM モータ, コギングトルク, 製造誤差, 非対称, 極数/スロット数比, パーミアンス分布

Keywords: PM motor, cogging torque, manufacturing error, asymmetry, pole/slot ratio, permeance distribution

\section{1. はじめに}

産業用や車載用などの分野でサーボ用途に使用される永 久磁石モー夕（以後，PM モー夕）に対し，位置決め精度 向上や騒音・振動低減の観点からコギングトルク低減への 厳しい要求がある ${ }^{(1) \sim(3)}$ 。コギングトルクはモータ内部の磁 気エネルギーが回転子位置によって変化するために生じる ものであり, 磁気エネルギーの総和を回転子位置で偏微分 することで求められる(4)(5)。コギングトルクを低減するに は極数とスロット数の適切な選定（多極化，分数スロット 化, 極数とスロット数の比の選定など）が有効であるほか, ティースや永久磁石の形状の工夫，さらにはスキューや補 助溝などの手法も知られており ${ }^{(4) \sim(6)}$, これらの設計手法に より理想的にはほぼ零にまで低減できる。

ところが量産時のモータにおいては, 形状誤差や磁石特

\footnotetext{
*三菱電機（株）

于 661-8661 尼崎市塚口本町 8-1-1

Mitsubishi Electric Corporation

8-1-1, Tsukaguchi-Honmachi, Amagasaki 661-8661
}

性のばらつき，鉄心磁気特性の不均一性といった，設計段 階の理想状態にはない様々な製造誤差要因により想定と異 なる脈動数成分のコギングトルクが発生することがある。 設計諸元によっては誤差要因により生じたコギングトルク 成分の脈動振幅が設計時に想定された成分の振幅よりも大 きくなることがあり，設計や工程の見直しが必要となるな ど，その影響も大きいものとなる。こういった誤差要因は モー夕性能向上の面からは完全に排除するのが理想である が,一般にコスト増大につながるため, 量産時にはある範 囲でこれを許容する必要がある。この際, 誤差要因とコギ ングトルクとの相関を正しく評価し，影響度に応じて誤差 を許容することが必要となる。

各種誤差要因に対する研究報告事例には，分割鉄心構造 の影響も含め固定子の歪や偏心などの形状精度の影響を検 討した報告 (7) (9) や，回転子側の様々な誤差要因に関する影 響度合いを評価した報告 ${ }^{(10)}$, 鉄心材料の磁気異方性や応力 による磁気特性劣化の影響を検討した報告 (11) (14) などがあ る。一方, モータ内部でのパーミアンス及び起磁力の分布 を周方向位置及び回転子の回転角度の関数として表記し, 
これを用いてモータ内部磁気エネルギーないしモー夕特性 を算出する報告がなされている(4)(15)。これを拡張し, 誤差 要因も含めた検討を行うことで, 種々の設計仕様に対し誤 差要因の空間分布状況とコギングトルク特性の関係を把握 できれば，コギングトルクに対する量産時のロバスト性を 含めたモー夕設計が可能となり産業上有用である。

本論文ではまず，モー夕内部の磁気エネルギー分布に基つ いてコギングトルクにつながる製造誤差要因の空間分布条件 を導く(16)。検討対象は表面磁石形永久磁石モー夕 (SPMSM) とする。誤差要因としては固定子側の因子を取り上げ，こ れをパーミアンス分布として扱う。次に，極数とスロット 数の比（以後，極数/スロット数比と呼ぶ）が異なる代表 的な種々の設計仕様に対しコギングトルクが発生するため の誤差要因の空間分布条件を具体的に示し，傾向の違いを 論じる。さらに上述の各種仕様に対し固定子内径に与える 歪の形状を種々変更して磁界解析を行い, 歪形状と発生す るコギングトルクの脈動数との関係から先に示した空間分 布条件の妥当性を検証する。

\section{2. モータ内部の磁気エネルギーとコギングトルク 発生の一般条件 ${ }^{(4)(5)(15)}$}

この章では，PM モー夕に蓄えられた磁気エネルギーの 分布関数から出発して，コギングトルクが発生する条件を 示す。次に回転子磁極及び固定子鉄心のスロットが全周で 対称に作られたモー夕において，一般に知られるコギング トルク発生条件を導く。なお本論文では，種々の物理量に 対し 1 周あたり $n$ 回の脈動を示す成分をその物理量の空間 $n$ 次成分と呼び，また極対数を $p$ としてロー夕 1 回転あた $り(k \cdot p)$ 回, 即ち電気角 360 度あたり $k$ 回の脈動を示す コギングトルクを“ $k$ 次成分のコギングトルク”と呼ぶ。ま た，鉄心に扔ける磁気飽和の影響は無視する。

$\langle 2 \cdot 1\rangle$ 磁気エネルギーの分布関数表現とコギングトル ク発生の一般的条件 $\quad \mathrm{PM}$ モータのコギングトルク $T_{C}(\theta)$ は, 回転子の回転角 $\theta$ と, そのときの空隙部磁気エネルギー $W_{g}(\theta)$ を用いて, 仮想仕事の原理から次式で与えられる。

$$
T_{C}(\theta)=-\frac{\partial W_{g}(\theta)}{\partial \theta} .
$$

ただし，磁石内部の磁気エネルギーはほぼ一定であり，鉄 心内部のエネルギーは非常に小さいので，それらの変化分 は無視している。次に回転子位置が $\theta$ のときの空隙部の磁 気エネルギー $W_{g}(\theta)$ を求める。位置 $\varphi$ にある微小区間に蓄 えられる磁気エネルギー密度 $\Delta w_{g}(\theta, \varphi)$ は, その位置の磁束 密度 $B_{g}(\theta, \varphi)$ と真空の透磁率 $\mu_{0}$ を用いて次式で表される。

$$
\Delta w_{g}(\theta, \varphi)=\frac{B_{g}^{2}(\theta, \varphi)}{2 \mu_{0}}
$$

空隙部の全磁気エネルギーは，これに微小区間の体積を乗 じ，位置 $\varphi$ で積分することで算出される。

$$
\begin{aligned}
W_{g}(\theta) & =l_{g} l_{s} r_{g} \cdot \oint_{C} \Delta w_{g}(\theta, \varphi) d \varphi \\
& =\frac{l_{g} l_{s} r_{g}}{2 \mu_{0}} \oint_{C} B_{g}^{2}(\theta, \varphi) d \varphi \ldots
\end{aligned}
$$

ここで, $l_{q}$ : 空隙長, $l_{S}$ : 軸長, $r_{q}$ : 空隙の半径。

回転機では, 空隙磁束密度分布関数 $B_{g}(\theta, \varphi)$ は任意の $\theta$ に対し, 位置 $\varphi$ が機械角 $2 \pi$ だけ変動する毎に必ず周期性 を持つ。よって空隙磁束密度を二乗した分布関数 $B_{q}^{2}(\theta, \varphi)$ も, 位置 $\varphi$ に対し機械角 $2 \pi$ ないしその整数倍の周期をも つ関数の和として表現できる。即ち,

$$
\begin{aligned}
& B_{g}^{2}(\theta, \varphi)=\sum_{n=0}^{\infty}\left(B_{g}^{2}\right)_{n} \cdot \cos \left\{n \cdot \varphi+f(n) \cdot \theta+\delta_{n}\right\} \cdots \\
& \text { ここで, }\left(B_{g}^{2}\right)_{n}: B_{g}^{2}(\theta, \varphi) \text { を } \varphi \text { でフーリ工級数展開 } \\
& \text { したときの第 } n \text { 次成分 (空間 } n \text { 次成分) の振幅, } \\
& f(n): \theta \text { の倸数, } \delta_{n}: \text { 第 } n \text { 次成分の初期位相。 }
\end{aligned}
$$

(4) 式において，空間次数 $n$ が 1 以上の成分は，(3) 式 に従って位置 $\varphi$ に対し機械角 $2 \pi$ の区間で積分すると零に なる。よって, $W_{g}(\theta)$ が零でない值を持つための条件は, (4) 式に㧍いて空間次数が零の成分が存在することである。 また，この空間零次成分が回転子位置 $\theta$ に対して変動する ときにコギングトルクが発生する。つまり(4) 式において $\left(B_{g}^{2}\right)_{0} \neq 0, f(n) \neq 0$ であることがコギングトルク発生の条 件となる。

$\langle\mathbf{2} \cdot \mathbf{2}\rangle$ 起磁力およびパーミアンス分布の満たすべき条 件 次に, 上で求めた条件から出発して, ある脈動数のコ ギングトルクが発生するための起磁力及びパーミアンス分 布の満たすべき条件を導出する。ある位置での空隙磁束密 度 $B_{g}(\theta, \varphi)$ は, その位置での起磁力分布関数 $F(\theta, \varphi)$ とパー ミアンス分布関数 $\Lambda(\theta, \varphi)$ を用いて次式で表される。

$$
B_{g}(\theta, \varphi)=F(\theta, \varphi) \cdot \Lambda(\theta, \varphi) .
$$

(5) 式の両辺を二乗して,

$$
B_{g}^{2}(\theta, \varphi)=F^{2}(\theta, \varphi) \cdot \Lambda^{2}(\theta, \varphi)
$$

SPMSM の場合, 回転子の作るパーミアンス分布は場所に よらずほぼ一様である。よって空隙部のパーミアンス関数 $\Lambda(\theta, \varphi)$ の脈動成分は固定子のみにより規定され，回転子の 回転角 $\theta$ には依存しないため, 以降は $\Lambda(\varphi)$ と表記する。

(4) 式と同様にして, 空隙部のパーミアンスを二乗した関 数 $\Lambda^{2}(\varphi)$ も, 位置 $\varphi$ に対し機械角 $2 \pi$ ないしその整数倍の 周期をもつ周期関数の和として表現できる。即ち

$$
\Lambda^{2}(\varphi)=\sum_{i=0}^{\infty}\left(\Lambda^{2}\right)_{i} \cdot \cos \left(i \cdot \varphi+\delta_{i}\right) .
$$

次に空隙部の起磁力分布関数 $F(\theta, \varphi)$ について記す。コ ギングトルクを検討する際には固定子は無通電状態である ので，起磁力は回転子のみに存在する。よって $F(\theta, \varphi)$ は 回転子磁極のみにより規定される。起磁力を二乗した関数 
$F^{2}(\theta, \varphi)$ についても，(4) 式と同様に位置 $\varphi$ に対し機械角 $2 \pi$ ないしその整数倍の周期をもつ周期関数の和として表現で きるが，ここで各成分が回転子と同期して回転することに 注意して，以下のようになる。

$$
F^{2}(\theta, \varphi)=\sum_{j=0}^{\infty}\left(F^{2}\right)_{j} \cdot \cos \left\{j \cdot(\varphi-\theta)+\delta_{j}\right\} \cdots \cdots \cdots
$$

(7) 式，(8) 式を(6) 式に代入して

$$
\begin{aligned}
& B_{g}^{2}(\theta, \varphi) \\
& =\sum_{j=0}^{\infty} \sum_{i=0}^{\infty} \frac{\left(F^{2}\right)_{j} \cdot\left(\Lambda^{2}\right)_{i}}{2} \cdot \cos \left\{(j+i) \cdot \varphi-j \cdot \theta+\left(\delta_{j}+\delta_{i}\right)\right\} \\
& \quad+\sum_{j=0}^{\infty} \sum_{i=0}^{\infty} \frac{\left(F^{2}\right)_{j} \cdot\left(\Lambda^{2}\right)_{i}}{2} \cdot \cos \left\{(j-i) \cdot \varphi-j \cdot \theta+\left(\delta_{j}-\delta_{i}\right)\right\}
\end{aligned}
$$

前節の議論より，コギングトルク発生条件は，「(9) 式の 第 2 項において $\varphi$ の係数が零となる自然数 $i, j$ に対し，そ の振幅が零でないこと」である。即ち，ある自然数 $\kappa$ に対 して，起磁力を二乗した関数 $F^{2}(\theta, \varphi)$, パーミアンスを二 乗した関数 $\Lambda^{2}(\varphi)$ の空間第 $\kappa$ 次成分の振幅が共に值を持つ とき, 1 回転あたり $\kappa$ 回の脈動をもつコギングトルクが発 生する。

以上，ある脈動数のコギングトルクが発生するために起 磁力分布関数とパーミアンス分布関数が満たすべき条件を 導いた。これらの分布関数に含まれる空間次数成分は，磁 極とスロットの数及び形状により決定される。

〈2·3 対称なスロット付モータで発生するコギングト ルクここでは, 周方向の全周にわたり等間隔に回転子磁 極と固定子スロットを配した，対称形状を有する SPMSM において，一般に知られているコギングトルク発生条件を 導く。固定子に $Z_{s t}$ 個のスロットを有する場合のパーミアン ス分布は, 平滑パーミアンスと呼ばれる一定成分とスロット 有無による変動成分とが重畳されたものと考えることがで きる。またティース部とスロット部では一般に対称性を持 つとは限らない。これらを考慮し, パーミアンス関数 $\Lambda(\varphi)$ は，フーリエ級数展開して以下のように表現できる。

$$
\Lambda(\varphi)=\sum_{i_{1}=0}^{\infty} \Lambda_{i_{1}} \cdot \cos \left(i_{1} \cdot Z_{s t} \cdot \varphi+\delta_{i_{1}}\right) \ldots \ldots \ldots \ldots
$$

ここで, $i_{1}$ : 零以上の整数, $\left(i_{1} \cdot Z_{s t}\right):$ パーミアン 又分布関数の空間次数, $\Lambda_{i_{1}}, \delta_{i_{1}}$ : 空間 $\left(i_{1} \cdot Z_{s t}\right)$ 次 成分の振幅と初期位相。

(10) 式の両辺を二乗し, 次数毎に係数を整理しなおする, 以下のように表現できる。

$$
\Lambda^{2}(\varphi)=\sum_{i=0}^{\infty}\left(\Lambda^{2}\right)_{i} \cdot \cos \left(i \cdot Z_{s t} \cdot \varphi+\delta_{i}\right) \cdots \cdots \cdots \cdots
$$

次に起磁力について求める。各磁極はすべて対称に作ら れていると仮定しているので，起磁力分布関数は以下のよ
うに表現することができる。

$$
F(\theta, \varphi)=\sum_{j_{1}=0}^{\infty} F_{j_{1}} \cdot \cos \left\{\left(2 \cdot j_{1}+1\right) \cdot p \cdot(\varphi-\theta)+\delta_{j_{1}}\right\}
$$

ここで, $p$ :極対数, $j_{1}$ :零以上の整数, $\left(2 \cdot j_{1}+1\right) p$ :起 磁力分布関数の空間次数, $F_{j_{1}}, \delta_{j_{1}}$ : 空間 $\left(2 \cdot j_{1}+1\right) p$ 次成分の振幅と初期位相。

(12) 式の両辺を二乗し, 次数毎に係数を整理しな掞すと, 以下のように表現できる。

$$
F^{2}(\theta, \varphi)=\sum_{j=0}^{\infty}\left(F^{2}\right)_{j} \cdot \cos \left\{j \cdot 2 p \cdot(\varphi-\theta)+\delta_{j}\right\}
$$

(11) 式と (13) 式を(6) 式に代入し，次式を得る。

$$
\begin{aligned}
& B_{g}^{2}(\theta, \varphi) \\
& =\sum_{j=0}^{\infty} \sum_{i=0}^{\infty}\left[\frac{\left(F^{2}\right)_{j} \cdot\left(\Lambda^{2}\right)_{i}}{2} \cdot \cos \left\{\left(j \cdot 2 p+i \cdot Z_{s t}\right) \cdot \varphi-j \cdot 2 p \cdot \theta+\delta_{j}+\delta_{i}\right\}\right] \\
& +\sum_{j=0}^{\infty} \sum_{i=0}^{\infty}\left[\frac{\left(F^{2}\right)_{j} \cdot\left(\Lambda^{2}\right)_{i}}{2} \cdot \cos \left\{\left(j \cdot 2 p-i \cdot Z_{s t}\right) \cdot \varphi-j \cdot 2 p \cdot \theta+\delta_{j}-\delta_{i}\right\}\right]
\end{aligned}
$$

(14) 式に対し前節のコギングトルク発生条件を適用する。 第 1 項は条件を満たさないので, 第 2 項から「 $j \cdot 2 p-i \cdot Z_{s t}=0$ を満たす自然数 $(j, i)$ の組が存在すること」がコギングトルク 発生条件となる。このときの脈動数は 1 回転あたり $(j \cdot 2 p)$ 回, 即ち $\left(i \cdot Z_{s t}\right)$ 回となる。以上より, 対称に作られたモー タのコギングトルク脈動数は, 極数 $2 p$ と固定子スロット数 $Z_{s t}$ の最小公倍数ないしその整数倍であることが導かれた。

\section{3. 製造誤差に起因する成分とその発生条件}

〈3・1 製造誤差に起因するコギングトルク成分 実 機で発生する, 最小公倍数より脈動数の少ない代表的なコ ギングトルク成分は, 1 回転あたりスロット数 $Z_{s t}$ と同数な いしその整数倍の脈動数成分（以後，スロット数次成分と 呼ぶ）と，極数 $2 p$ と同数ないしその整数倍の脈動数成分 (同，極数次成分）である。本節ではこれらの成分が生じた 場合の製造誤差の発生部位について論じる。

まず，極数次成分のコギングトルクが発生する条件，即 ち〈2.2〉節で述べた $\kappa=2 k p$ となる条件を求める。起磁力 分布関数については，対称性を仮定した場合の表現式 (13) において $j \cdot 2 p=2 k p$ 即ち $j=k$ の条件が成り立てばよい ので, 通常の対称な回転子でも成立し得る。一方, パーミ アンス分布関数については, 対称性を仮定した場合, (11) 式に㧍いて $i \cdot Z_{s t}=2 k p$ を満たす自然数 $i, k$ が存在する 必要がある。これは言い換えると, $Z_{s t}$ が $2 k p$ の約数であ る」ことが条件となるが，この場合の発生次数は極数とス ロット数の最小公倍数成分もしくはその整数倍となり今回 の議論の対象外である。よって, 極数次成分のコギングト 
ルクが発生するためには，固定子側にスロット数の整数倍 以外の空間分布をもつパーミアンス脈動成分, 即ち, 固定 子側の製造誤差に起因する成分が含まれていることが必要 となる。

同様の考察により，スロット数次成分のコギングトルク が発生するためには回転子側の起磁力分布に極対数の奇数 倍以外の脈動成分，即ち，回転子側の製造誤差に起因する 成分が含まれている必要がある。

$\langle\mathbf{3} \cdot 2\rangle$ 極数次成分コギングトルクの発生条件＼cjkstart次に， 上で述べた中で固定子側の製造誤差に起因する極数次成分 のコギングトルクを取り上げ，これが発生するときの固定子 パーミアンス分布関数 $\Lambda(\varphi)$ の条件を求める。 $\Lambda(\varphi)$ におい て (14) 式で表現されたスロット数の整数倍の成分に加え, 1 回転あたり $N$ 回の脈動をもつ成分（ただし $N$ はスロット 数の整数倍でない整数; 以後, 非対称成分とよぶ) が重畳 された場合を考えると， $\Lambda(\varphi)$ は以下のように表現できる。

$$
\begin{aligned}
\Lambda(\varphi)= & \sum_{i_{1}=0}^{\infty} \Lambda_{i_{1}} \cdot \cos \left(i_{1} \cdot Z_{s t} \cdot \varphi+\delta_{i_{1}}\right) \\
& +\Lambda_{N} \cdot \cos \left(N \cdot \varphi+\delta_{N}\right) \ldots \ldots
\end{aligned}
$$

ここで, $\Lambda_{N}$ : 重畳された $N$ 次成分パーミアンス分 布の振幅， $\delta_{N}: N$ 次成分の初期位相。

(15) 式の第 1 項は (10) 式と同一であり，偶数を含む零〜 めまでの空間次数成分を有する。(15) 式の両辺を二乗し, 次数毎に係数を一部整理すると, 以下のように表現できる。

$$
\begin{aligned}
\Lambda^{2}(\varphi)= & \sum_{i_{1}=0}^{\infty} \cdot \sum_{i_{2}=0}^{\infty}\left\{\Lambda_{i_{1}} \cdot \Lambda_{i_{2}} \cdot \cos \left(i_{1} \cdot Z_{s t} \cdot \varphi+\delta_{i_{1}}\right)\right. \\
& \left.\cdot \cos \left(i_{2} \cdot Z_{s t} \cdot \varphi+\delta_{i_{2}}\right)\right\}+\Lambda_{N}^{2} \cdot \cos ^{2}\left(N \cdot \varphi+\delta_{N}\right) \\
& +\sum_{i_{1}=0}^{\infty} 2 \cdot \Lambda_{i_{1}} \cdot \Lambda_{N} \cdot \cos \left(i_{1} \cdot Z_{s t} \cdot \varphi+\delta_{i_{1}}\right) \cos \left(N \cdot \varphi+\delta_{N}\right) \\
= & \sum_{i=0}^{\infty}\left(\Lambda^{2}\right)_{i} \cdot \cos \left(i \cdot Z_{s t} \cdot \varphi+\delta_{i}\right) \\
& +\frac{1}{2} \Lambda_{N}^{2} \cdot\left\{\cos \left(2 N \cdot \varphi+2 \delta_{N}\right)+1\right\} \\
& +\sum_{i_{1}=0}^{\infty} \Lambda_{i_{1}} \cdot \Lambda_{N} \cdot \cos \left\{\left(i_{1} \cdot Z_{s t}+N\right) \cdot \varphi+\left(\delta_{i_{1}}+\delta_{N}\right)\right\} \\
& +\sum_{i_{1}=0}^{\infty} \Lambda_{i_{1}} \cdot \Lambda_{N} \cdot \cos \left\{\left(i_{1} \cdot Z_{s t}-N\right) \cdot \varphi+\left(\delta_{i_{1}}-\delta_{N}\right)\right\}
\end{aligned}
$$

極数次成分コギングトルクが発生する条件は, (16) 式で表さ れたパーミアンスの二乗の関数において, 空間次数が $\pm 2 k p$ のものが存在することである。(16) 式の第 1 項は (11) 式と 同一であり，前章の議論から極数次成分の原因とはなりえ ない。よって，以下の場合が考えられる。

[1] 第 2 項に $\pm 2 k p$ が存在 $\cdots N=k p$

[2] 第 3 項に $\pm 2 k p$ が存在 $\cdots N= \pm 2 k p-\left(i_{1} \cdot Z_{s t}\right)$

[3] 第 4 項に $\pm 2 k p$ が存在 $\cdots N=\left(i_{1} \cdot Z_{s t}\right) \pm 2 k p$
以上の検討結果から，固定子のパーミアンス分布に上記 3 つの条件のいずれかを満たす非対称成分が付加された場 合に極数次成分のコギングトルクが発生する。逆にこの条 件を満たす非対称成分が固定子のパーミアンス分布に付加 されなければ極数次成分のコギングトルクは発生しない。

上記の条件を満たす $i_{1}$ は無数に存在する。そこで，影響 度を検討すべく, 各成分の振幅について検討する。条件 [1] は極対数の整数倍と同じ脈動回数を持つパーミアンス脈動 が付加された場合であり，このときコギングトルクの大き さは, 付加された $N$ 次パーミアンス脈動の振幅 $\Lambda_{N}$ の二乗 に比例する。一方，上記の条件 [2]，［3］が成立するとき のコギングトルク振幅について考える。ある $N$ 次パーミア ンス脈動が付加されることで上記条件 [2] ないし [3] が 成立する時, 発生する極数次成分コギングトルクの振幅は, $\Lambda_{N}$ と，上式を満たす $i_{1}$ に対応する $\Lambda_{i_{1}}$ の双方に比例する。 上式における係数 $i_{1}$ は，スロットの作るパーミアンス脈動 関数をフーリエ級数展開したときの次数であり，対応する $\Lambda_{i_{1}}$ はパーミアンス脈動の振幅を表す。一般にスロットパー ミアンス脈動が矩形状に分布しているとすれば，次数が低 いほど振幅は大きくなる。よって, 付加された $N$ 次パーミ アンス脈動の振幅 $\Lambda_{N}$ の振幅が同程度であれば，次数 $i_{1}$ が 小さいほどコギングトルクの振幅は大きい。即ち, 条件を 満たす $i_{1}$ のうち, その值が小さいほど, 極数次成分コギン グトルクへの寄与度が大きい。

なお，実機においては上述の議論に加えて，鉄心の磁気 飽和の影響によっても空隙磁束密度に高調波成分が重畳さ れ，これがコギングトルクを引き起こす場合があることが 知られている (2)。より詳細な検討を行う際にはこれの影響 も併せて検討する必要がある。

\section{4. 種々のモータ設計仕様に対するコギングトルク の発生条件}

三相交流駆動の PM モータで代表的な極数／スロット数 比を 7 つ選び，各々について非対称成分のパーミアンスの 空間次数とコギングトルクの関係を調べる。各モデルの仕 様を表 1 に記す。Model 1 から Model 5 はいわゆる集中巻 方式を想定しており，代表的な極数／スロット数比である $2: 3,4: 3,8: 9,10: 9,5: 6$ の 5 種（毎極毎相スロッ 卜数 $q$ は各々 $1 / 2,1 / 4,3 / 8,3 / 10,2 / 5)$ をとりあげた。 Model 6 と Model 7 は分布巻を想定しており，それぞれ整 数スロット（同 1）および分数スロット（同 3/2）とした。 極数は 8 極ないし 10 極とし, 全モデルでほぼ等しくなる よう配慮した。

まず, Model $3\left(2 p=8, Z_{s t}=9\right)$ を例に, 2 次成分の コギングトルクの発生条件を具体的に示す。条件 [1] から は， $N=4$ が該当する。条件 [2] からは， $N= \pm 8-i_{1} \times 9$ であり， $i_{1} \geq 0$ かつ $N>0$ となるのは $N=8$ (このとき $\left.i_{1}=0\right)$ の場合のみである。条件 [3] からは, $N=i_{1} \times 9 \pm 8$ であり, 複号が正のとき, $i_{1}=0,1,2,3, \cdots$ において $N=8,17,26,35, \cdots$, 複号が負のとき, $i_{1}=1,2,3$, 
表 1 検証に用いた 7 種類のモータの極数一スロット数組合せ

Table 1. Combination of pole number and slot number for seven verification motors.

\begin{tabular}{|c|c|c|c|c|c|cc|c|}
\hline $\begin{array}{c}\text { Model } \\
\text { No. }\end{array}$ & $\begin{array}{c}\text { Number of } \\
\text { Poles }(2 p)\end{array}$ & $\begin{array}{c}\text { Number of } \\
\text { Slots }\left(Z_{s t}\right)\end{array}$ & $\begin{array}{c}\text { Pole/slot } \\
\text { ratio }\end{array}$ & $\begin{array}{c}\text { L.C.M. of } 2 p \\
\text { and } Z_{s t}(L C M)\end{array}$ & $(L C M / p)$ & \multicolumn{2}{|c|}{$\begin{array}{c}\text { Number of Slot } \\
\text { per Pole per Phase }(q)\end{array}$} & $\begin{array}{c}\text { Typical Winding } \\
\text { Pattern }\end{array}$ \\
\hline Model 1 & 8 & 12 & $2: 3$ & 24 & 6 & $1 / 2$ & (Fractional) & Concentrated \\
\hline Model 2 & 8 & 6 & $4: 3$ & 24 & 6 & $1 / 4$ & (Fractional) & Concentrated \\
\hline Model 3 & 8 & 9 & $8: 9$ & 72 & 18 & $3 / 8$ & (Fractional) & Concentrated \\
\hline Model 4 & 10 & 9 & $10: 9$ & 90 & 18 & $3 / 10$ & (Fractional) & Concentrated \\
\hline Model 5 & 10 & 12 & $5: 6$ & 60 & 12 & $2 / 5$ & (Fractional) & Concentrated \\
\hline Model 6 & 8 & 24 & $1: 3$ & 24 & 6 & 1 & (Integral) & Distributed \\
\hline Model 7 & 8 & 36 & $2: 9$ & 72 & 18 & $3 / 2$ & (Fractional) & Distributed \\
\hline
\end{tabular}

表 22 次成分コギングトルクが発生するためのパーミアンス分布関数の満たすべき空間次数条件

Table 2. Space order of permeance distribution function that 2 nd order cogging torque will be generated.

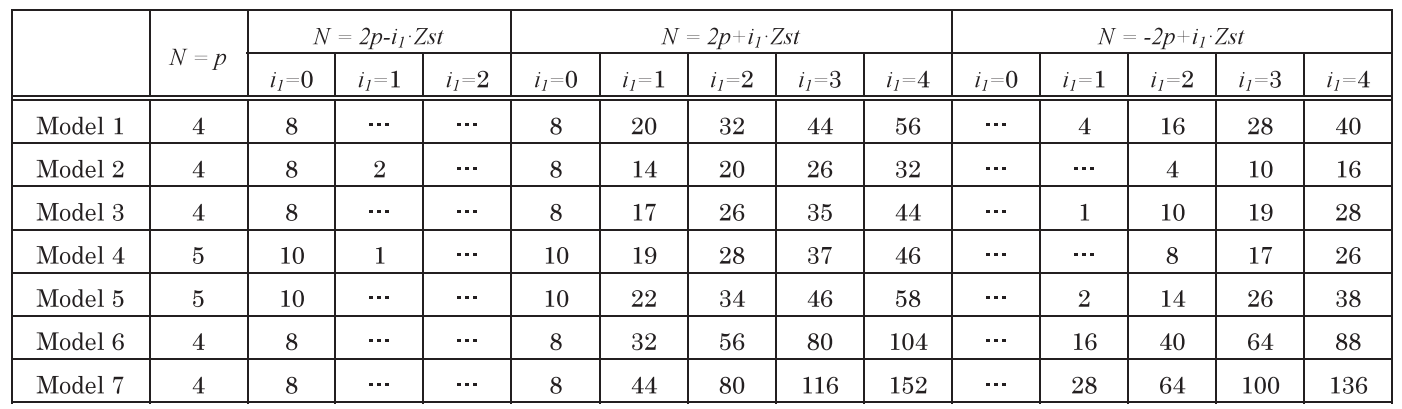

表 $32 k$ 次成分コギングトルクの原因となるパーミアンス分布関数の空間次数（理論式からの予測；15 次以下のもの）

Table 3. Space order of permeance distribution that generates " $2 k$ "-th order cogging torque (calculated).

\begin{tabular}{|c|c|c|c|c|c|c|c|c|c|}
\hline \multirow{2}{*}{$\begin{array}{c}\text { Model } \\
\text { No. }\end{array}$} & \multicolumn{10}{|c|}{\begin{tabular}{c} 
2nd \\
\cline { 2 - 11 }
\end{tabular}} & $\begin{array}{c}4 \text { th } \\
(k=2)\end{array}$ & $\begin{array}{c}6 \text { th } \\
(k=3)\end{array}$ & $\begin{array}{c}8 \text { th } \\
(k=4)\end{array}$ & $\begin{array}{c}10 \text { th } \\
(k=5)\end{array}$ & $\begin{array}{c}12 \text { th } \\
(k=6)\end{array}$ & $\begin{array}{c}14 \text { th } \\
(k=7)\end{array}$ & $\begin{array}{c}16 \text { th } \\
(k=8)\end{array}$ & $\begin{array}{c}18 \text { th } \\
(k=9)\end{array}$ \\
\hline 1 & 4,8 & 4,8 & $\ldots$ & 4,8 & 4,8 & $\ldots$ & 4,8 & 4,8 & $\ldots$ \\
\hline 2 & $2,4,8,10,14$ & $2,4,8,10,14$ & $\ldots$ & $2,4,8,10,14$ & $2,4,8,10,14$ & $\ldots$ & $2,4,8,10,14$ & $2,4,8,10,14$ & $\ldots$ \\
\hline 3 & $1,4,8,10$ & $2,7,8,11$ & $3,6,12,15$ & $4,5,13,14$ & $4,5,13,14$ & $3,6,12,15$ & $2,7,11$ & $1,8,10$ & $\ldots$ \\
\hline 4 & $1,5,8,10$ & $2,7,10,11$ & $3,6,12,15$ & $4,5,13,14$ & $4,5,13,14$ & $3,6,12,15$ & $2,7,11$ & $1,8,10$ & $\ldots$ \\
\hline 5 & $2,5,10,14$ & $4,8,10$ & 6,15 & 4,8 & $2,10,14$ & $\ldots$ & $2,10,14$ & 4,8 & 6 \\
\hline 6 & 4,8 & 8 & $\ldots$ & 8 & 8 & $\ldots$ & 8 & 8 & $\ldots$ \\
\hline 7 & 4,8 & 8 & 12 & 4 & 4 & 12 & $\ldots$ & & 8 \\
\hline
\end{tabular}

$\cdots$ において $N=1 ， 10 ， 19 ， \cdots$ となる。前述のように， 条件 [2]，［3］が成立するとき， $i_{1}$ が小さいほどコギング トルク振幅が大きいので, $N=1,4,8,10,17, \cdots$ など のパーミアンス脈動が生じたときに 2 次成分のコギングト ルクが発生すると予想される。

同様にして，7つのモデルに対し 2 次成分コギングトル クが発生するための条件を $i_{1} \leq 4$ の範囲で求めた。結果を 表 2 に記す。表中, ‥⿱一兀表した部分は, 条件を満たす自然数 $N$ が存在しないことを表す。表 2 から，いずれのモー夕も 極対数 $p$ ないし極数 $2 p$ と一致する空間次数をもつパーミ アンス脈動が付加された場合に 2 次成分コギングトルクが 生じる。また, 極数/スロット数比が $2: 3$ の場合 (Model 1）と分布巻の場合 (Model 6 と Model 7), 即ち $q$ が $1 / 2$
以上の場合には極対数成分以下の低次成分の影響を受けな いのに対し，それ以外の場合には空間 1 次，2次といった 低次成分の影響によって 2 次成分のコギングトルクが発生 する。

7 種のモータに対し 4 次〜 18 次成分のコギングトルクが 発生する条件を同様に求めた。非対称成分の空間次数 $N$ と して今回は 15 次までの範囲に限定して記した。結果をまと めて表 3 に示す。前述の 2 次成分と同様, 4 次以上の成分に ついても, $q$ が 1/2 以上の場合 (Model 1, Model 6, Model 7）には，極対数より低次の空間次数成分の影響を受けない のに対し，それ以外では低次成分の影響を受けることがわ かる。また，上述の条件範囲において Model 1, Model 6, Model 7 のコギングトルク特性に影響を与えるのは空間 4 


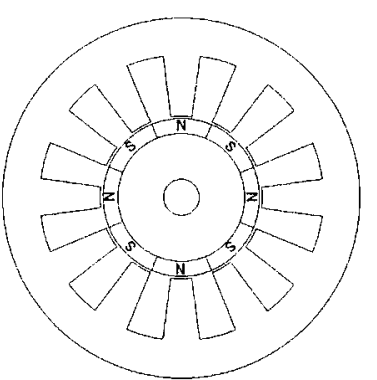

(a) Model 1 (8poles 12slots)

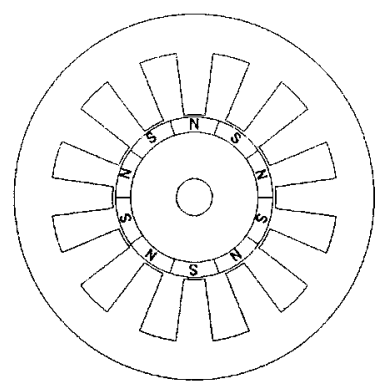

(e) Model 5 (10poles 12slots)

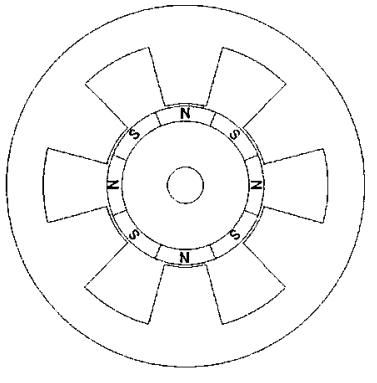

(b) Model 2 (8poles 6slots)

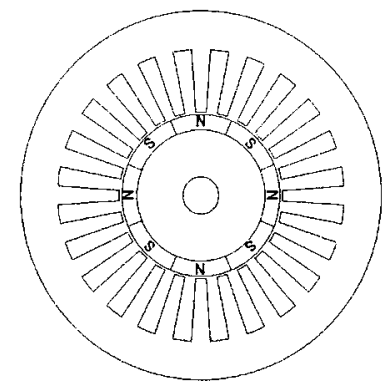

(f) Model 6 (8poles 24slots)

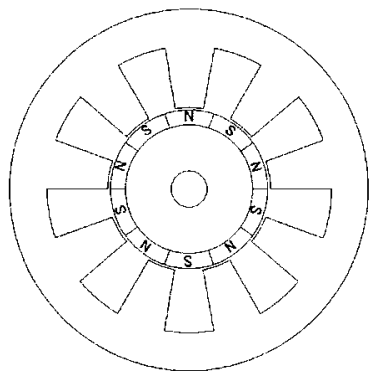

(d) Model 4 (10poles 9slots)

(c) Model 3 (8poles 9slots)

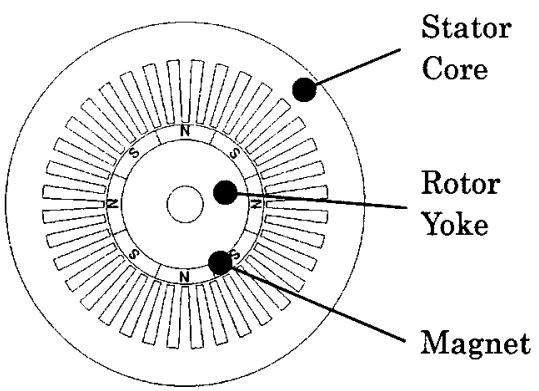

(g) Model 7 (8poles 36slots)

図 1 検証用モー夕の断面形状

Fig. 1. Cross section of the verification motor.

表 4 検証用モー夕の諸元

Table 4. Specifications of the verification motor.

\begin{tabular}{|c|c|}
\hline Rotor outer Diameter [mm] & 35 \\
\hline Rotor inner Diameter [mm] & 8 \\
\hline Stator outer Diameter [mm] & 80 \\
\hline Air Gap [mm] & 0.6 \\
\hline Core Length [mm] & 40 \\
\hline $\begin{array}{c}\text { Slot Opening Ratio } \\
\text { (slot opening width / teeth pitch) }\end{array}$ & $1 / 2$ \\
\hline Width of Stator core back [mm] & 8.3 \\
\hline $\begin{array}{c}\text { Material of Rotor Yoke and Stator Core } \\
\text { (JIS C 4051) }\end{array}$ & Ring \\
\hline Shape of Permanent Magnet & 3.3 \\
\hline Thickness of Permanent Magnet [mm] & 1.4 \\
\hline $\begin{array}{c}\text { Residual Magnetic Flux Density of } \\
\text { Permanent Magnet [T] }\end{array}$ & Radia] \\
\hline Magnetization Pattern & \\
\hline
\end{tabular}

次成分, 8 次成分などの限られた歪成分のみであり，他の空 間次数成分の歪が加わっても影響がないと予想される。一 方, Model 3, Model 4 では空間 9 次成分 (スロット数と同 数の成分）以外のいずれの歪成分を付加した場合でもコギ ングトルク特性に影響が現れており，生じるコギングトル ク次数も各々異なる傾向を示す。Model 2, Model 5 でも同 様に，ほとんどの空間次数の歪成分を付加した場合でコギ ングトルク特性に影響が現れている。この結果から，qが 1/2 以上の場合 (Model 1, Model 6, Model 7) に比べ, そ れ以外のモデルでは歪の影響を受けやすいと考えられる。

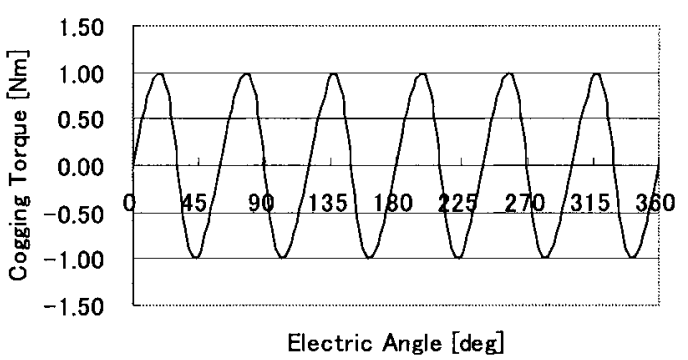

(a) without distortion

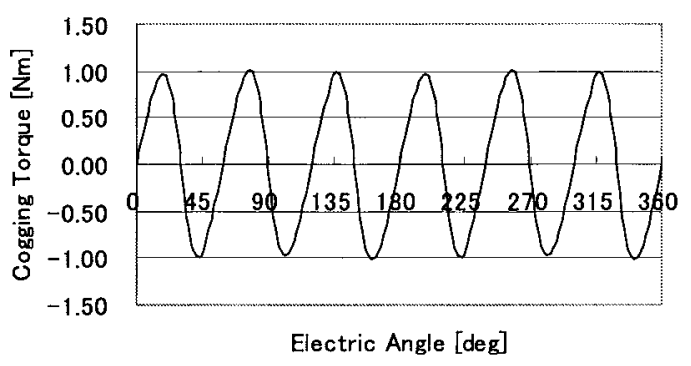

(b) with distortion of mode 4

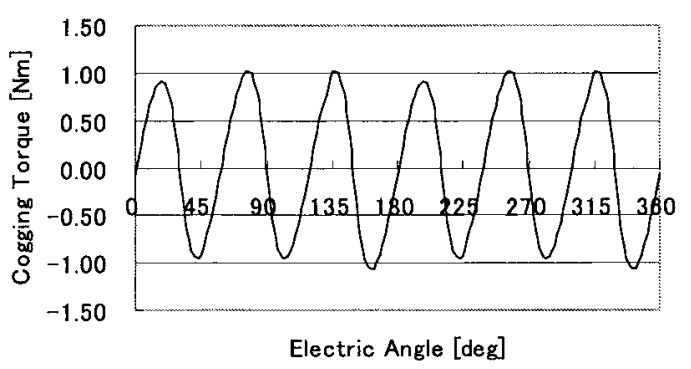

(c) with distortion of mode 8

図 2 コギングトルク波形（解析結果： Model $1=8$ 極 12 スロット)

Fig. 2. Cogging torque waveform with/without distortion (analyzed; Model $1=8$ poles 12 slots). 


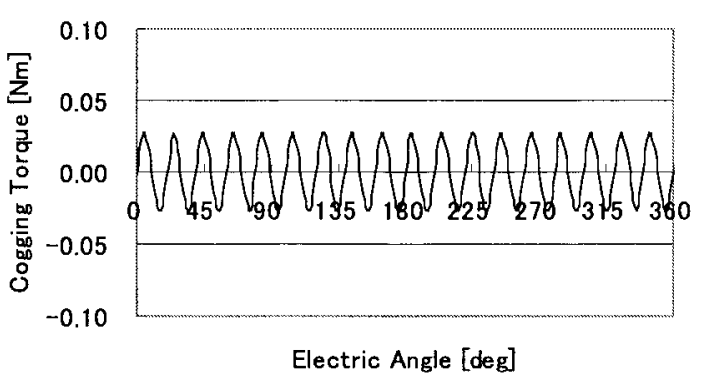

(a) without distortion

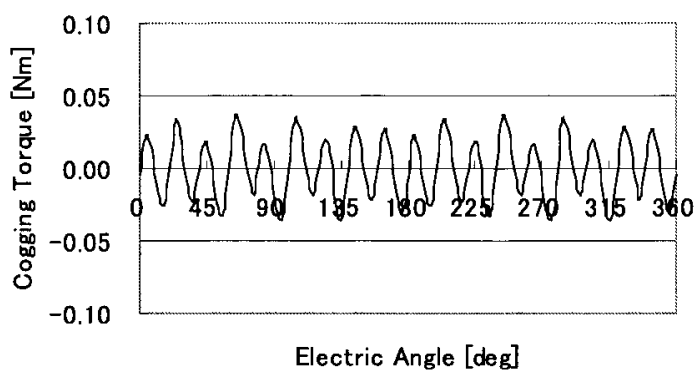

(b) with distortion of mode 4

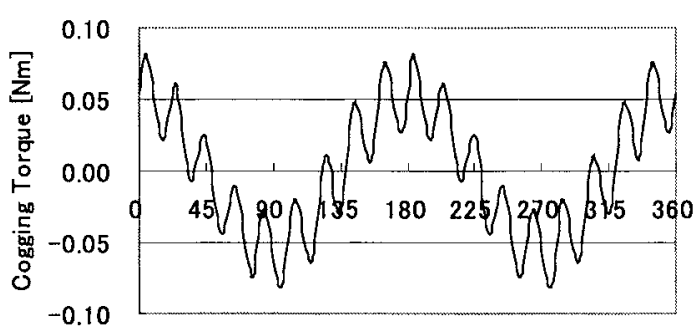

Electric Angle [deg]

(c) with distortion of mode 8

図 3 コギングトルク波形（解析結果：

Model $3=8$ 極 9 スロット)

Fig. 3. Cogging torque waveform with/without distortion (analyzed; Model $3=8$ poles 9 slots).

\section{5. 磁界解析による検証}

前章で述べた関係式を確かめるべく，具体的なモー夕仕 様に対して特定の空間次数を持つパーミアンス分布を付加 し，パーミアンス分布関数の空間次数とコギングトルク発 生状況の関係を調べた。実機では複数の因子が加わること が多く因子の切り分けが難しいため, 本論文では磁界解析 を用いることで付加した誤差要因の影響のみを切り分ける こととした。製造誤差因子としては, 固定子の内径に歪を 与えることで非対称性を付与した。

$\langle\mathbf{5} \cdot \mathbf{1}\rangle$ 対象モータの諸元 対象とした 7 種のモー夕 各々の断面形状を図 $1(\mathrm{a}) \sim(\mathrm{g})$ に，共通諸元を表 4 に示す。 極数/スロット数比の異なる 7 種のモー夕に対し, 固定子 内径形状に特定の空間次数の歪を与えたコギングトルク解 析を行い, 歪の空間次数とコギングトルクの関係を検討し た。付加する歪の空間次数は前章と同様に $1 \sim 15$ とし, 固 定子内径を設計寸法に対し $\pm 30 \mu \mathrm{m}$ で変化させた。なお，極 数 ノスロット数比以外のパラメータ, 例えば鉄心や永久磁 石材料の磁気特性, スロットやティース, 永久磁石の詳細

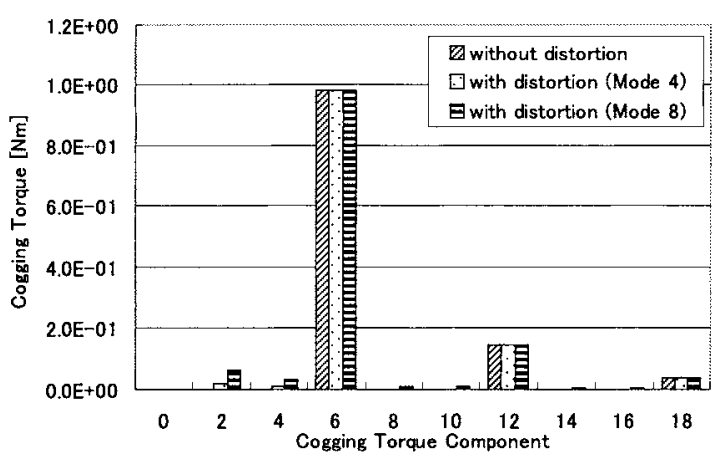

図 4 コギングトルク成分分析結果

(Model $1=8$ 極 12 スロット)

Fig. 4. Cogging torque components with/without distortion (Model $1=8$ poles 12 slots).

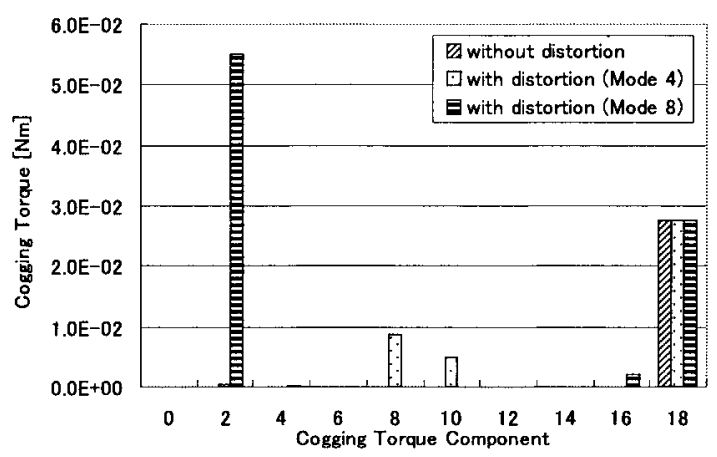

図 5 コギングトルク成分分析結果 (Model $3=8$ 極 9 スロット)

Fig. 5. Cogging torque components with/without distortion (Model $3=8$ poles 9 slots).

形状，空隙長などは全て同一とし，付加した歪の空間次数 とコギングトルクとの定性的関係のみを検討した。

$\langle\mathbf{5} \cdot \mathbf{2}\rangle$ 解析結果と理論発生次数との比較 一例とし て, 前章で歪の影響を受けにくいと予測した Model 1 と, 逆に受けやすいと予測した Model 3 について, 磁界解析結 果をそれぞれ図 2, 図 3 に示す。両図において (a) は歪の ない場合，(b) および (c) はそれぞれ空間 4 次および 8 次成 分の歪を与えた場合である。横軸は回転角度を電気角で示 す。これらの成分分析結果を図 4, 図 5 に示す。次数は 18 次までを示した。歪がないとき, Model 1 では 6 次拉よび その整数倍である 12 次, 18 次の成分が, Model 3 では 18 次成分のみが発生している。これに対し，Model 1 で空間 4 次ないし 8 次成分の歪を与えると, 2 次ないし 4 次成分 のコギングトルクが重畳されるほか, 值は小さいものの 8 次, 10 次, 14 次, 16 次などの成分も発生している。また, 歪のない状態で元々発生していた 6 次, 12 次, 18 次成分 にはほとんど変化がない。一方, Model 3 では空間 4 次成 分の歪を与えると 2 次, 8 次, 10 次成分のコギングトルク が, 空間 8 次成分の歪を与えると 2 次, 16 次成分のコギン グトルクがそれぞれ重畳されている。

他の空間次数成分を持つ歪を与えた場合についても同様 の計算を行い, 成分分析して比較した。図 6 , 図 7 に結果 

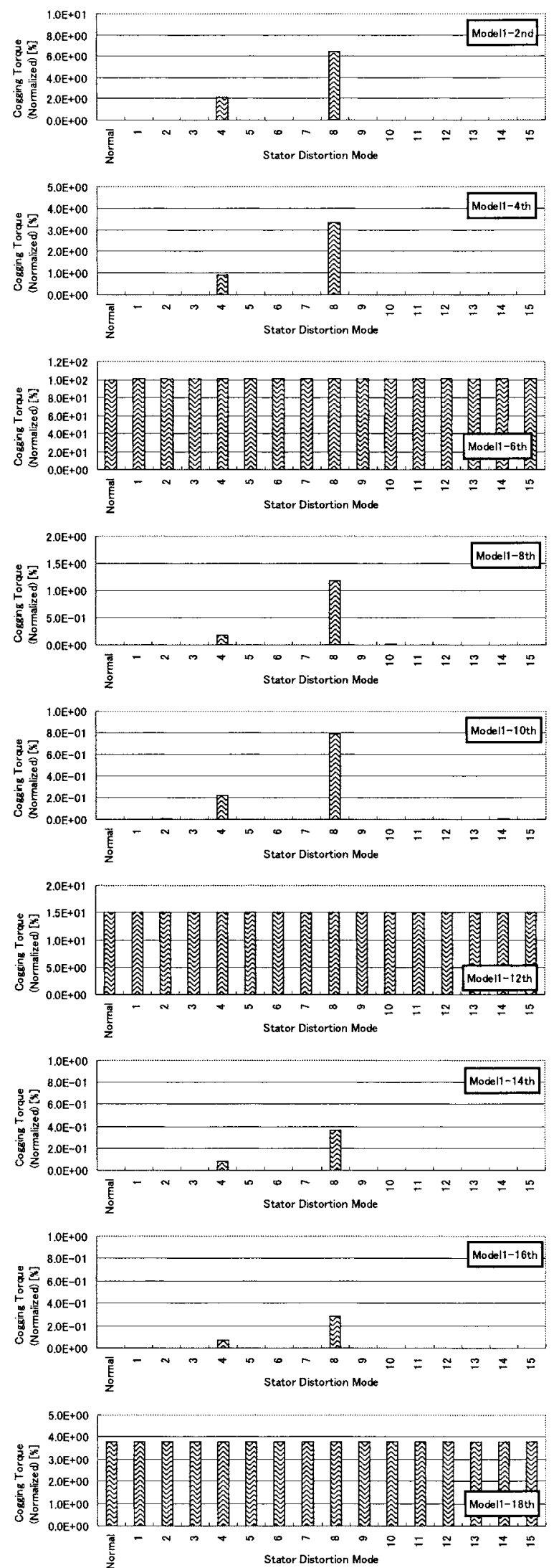

図 6 固定子内径変形モードとコギングトルク脈 動数の関係（解析結果： Model $1=8$ 極 12 ス ロット)

Fig. 6. Relationship between stator distortion mode and cogging torque (Model $1:$ 8poles 12slots).
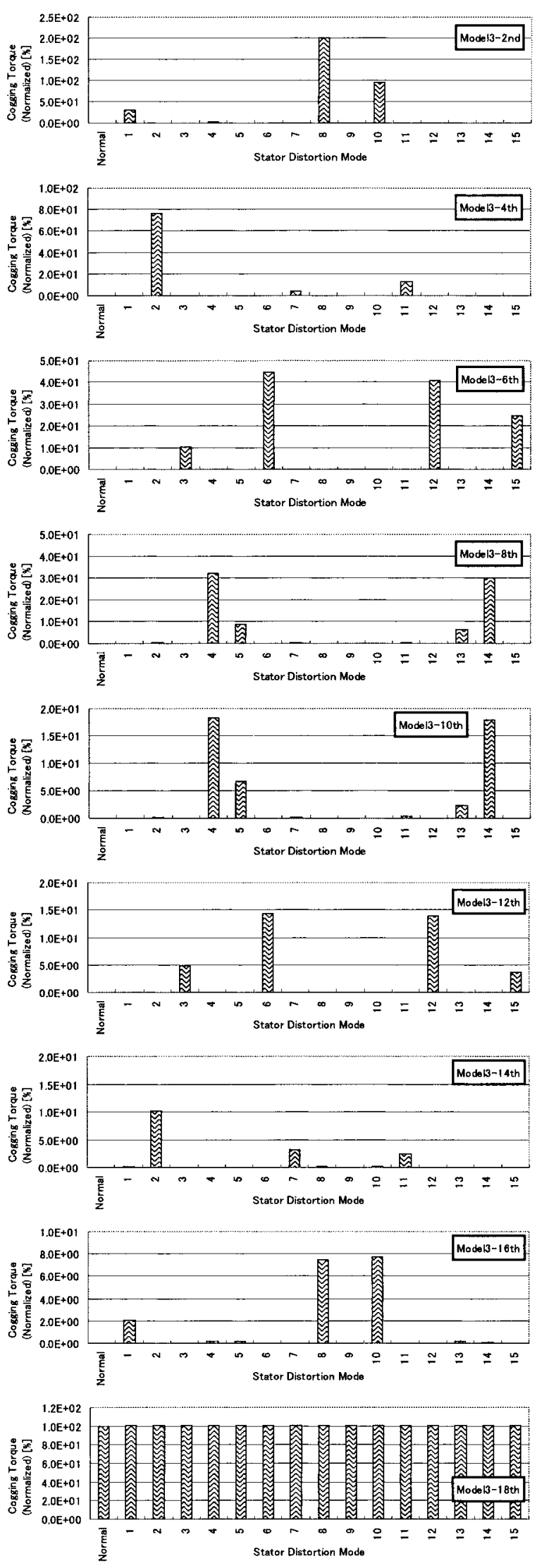

図 7 固定子内径変形モードとコギングトルク脈動数の 関係（解析結果：Model $3=8$ 極 9 スロット）

Fig. 7. Relationship between stator distortion mode and cogging torque (Model 3 : 8poles 9slots). 
表 $52 k$ 次成分コギングトルクを発生させる空間次数 15 次以下の固定子内径歪成分

(解析結果；しきい值 $=0.5 \mathrm{mN} \cdot \mathrm{m}$ 以上)

Table 5. Space order of stator distortion that caused " $2 k$ "-th order cogging torque (analyzed results; threshold level is $0.5 \mathrm{mN} \cdot \mathrm{m}$ ).

\begin{tabular}{|c|c|c|c|c|c|c|c|c|c|}
\hline \multirow{2}{*}{$\begin{array}{c}\text { Model } \\
\text { No. }\end{array}$} & \multicolumn{9}{|c|}{ Cogging torque components } \\
\hline & $\begin{array}{l}\text { 2nd } \\
(k=1)\end{array}$ & $\begin{array}{c}4 \text { th } \\
(k=2)\end{array}$ & $\begin{array}{c}6 \text { th } \\
(k=3)\end{array}$ & $\begin{array}{c}8 \text { th } \\
(k=4)\end{array}$ & $\begin{array}{c}10 \text { th } \\
(k=5)\end{array}$ & $\begin{array}{c}12 \text { th } \\
(k=6)\end{array}$ & $\begin{array}{c}14 \text { th } \\
(k=7)\end{array}$ & $\begin{array}{c}16 \text { th } \\
(k=8)\end{array}$ & $\begin{array}{c}18 \text { th } \\
(k=9)\end{array}$ \\
\hline 1 & 4,8 & 4,8 & $\ldots$ & 4,8 & 4,8 & $\ldots$ & 4,8 & 4,8 & $\ldots$ \\
\hline 2 & $2,4,8,10,14$ & $2,4,8,10,14$ & $\cdots$ & $2,4,8,10,14$ & $2,4,8,10,14$ & $\cdots$ & $2,4,8,10,14$ & $2,4,8,10,14$ & $\cdots$ \\
\hline 3 & $1,4,8,10$ & $2,7,11$ & $3,6,12,15$ & $4,5,13,14$ & $4,5,13,14$ & $3,6,12,15$ & $2,7,11$ & $1,8,10$ & $\cdots$ \\
\hline 4 & $1,5,8,10$ & $2,7,11$ & $3,6,12,15$ & $4,5,13,14$ & $4,5,13,14$ & $3,6,12,15$ & $2,7,11$ & 8,10 & $\ldots$ \\
\hline 5 & $2,5,10,14$ & 4,8 & 6 & 4,8 & 2,10 & $\ldots$ & 2,14 & 8 & 6 \\
\hline 6 & 4,8 & 8 & $\cdots$ & 8 & 8 & $\cdots$ & 8 & 8 & $\cdots$ \\
\hline 7 & 4,8 & $2+2$ & 12 & 4 & 4 & 12 & $\cdots$ & 8 & $\ldots$ \\
\hline
\end{tabular}

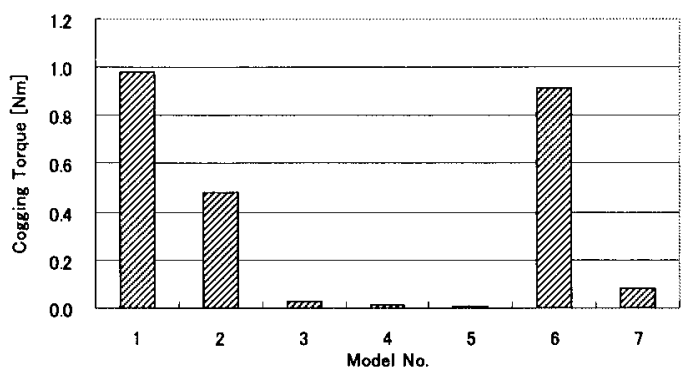

図 8 歪がないときの各モデルのコギングトルク振幅

Fig. 8. Amplitude of cogging torque for seven models (without distortion).

を示す。ただし，各成分の振幅に差があるため，付加した 歪の次数が異なる 16 種類の解析を各々実施した後, 2 次〜

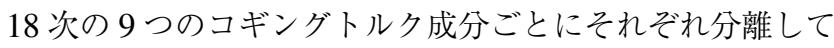
グラフ化してある。各図において横軸は付加された内径歪 の空間次数を, 縦軸はコギングトルク振幅を表す。縦軸は, 歪のない状態の各モデルのコギングトルク振幅值（図 8）に 対する百分率で表記した。図 6 から，上述の条件範囲にお いて Model 1 のコギングトルク特性に影響を与えるのは空 間 4 次, 8 次成分の歪のみであり, 他の空間次数成分の歪 が加わっても影響がないことがわかる。一方，図７からわ かるように Model 3 では空間 9 次成分以外のいずれの歪成 分を付加した場合でもコギングトルク特性に影響が現れて おり, 生じるコギングトルク次数も各々異なる傾向を示す。

同様の解析を各モデルに対して行い，各次数成分のコギ ングトルクの発生原因となる固定子内径歪の空間次数を調 べた。結果を表 5 に示す。ただし解析誤差の影響を除くた め，成分分析後の振幅が $0.5 \mathrm{mN} \cdot \mathrm{m}$ 以下の成分，すなわち 歪がないときにコギングトルクが最も小さい Model 5 の振 幅值 $6.8 \mathrm{mN} \cdot \mathrm{m}$ の約 7\%以下の振幅值を持つ成分は, 実用上 も影響が小さく無視できるレベルであるとみなした。

表 5 の結果は, 理論式による予測結果（表3）と全般的に ほぼ一致している。表 5 の網掛け部分は表 3 と一致してい ないが，いずれも，理論式でコギングトルクの発生が予測 される歪を与えたにもかかわらず解析で当該成分が発生し
ない結果となっている。この結果から，振幅が大きいコギ ングトルク成分については, 提案した理論式を用いて原因 となる固定子歪の空間次数を正確に予測できたといえる。

次に, 理論式からの予測結果と異なる成分について検討 する。4 次及び 6 次成分コギングトルクの原因として予測 と一致していないのは, 条件 [1] から導かれた空間次数成 分である。この成分のコギングトルク振幅は歪量の二乗に 比例するため, 与えられた歪の振幅が小さい場合には条件 [2]，［3］から導かれた成分に比べ振幅が小さくなる。今 回の解析で与えた歪の振幅 $30 \mu \mathrm{m}$ は空隙長の高々 $5 \%$ であ り, 解析誤差レベルの振幅でしか発生しなかったものと考 えられる。一方, 10 次, 14 次及び 16 次成分については条 件 [2]，［3］功導かれた成分である。この成分はスロッ 卜開口部の幅に大きく依存し, 今回設定したモータ形状に おいて当該成分の振幅が小さくなったと考えられる。

以上の結果より, 提案した理論式を用いることで, 固定 子内径に付加された歪の空間次数に対し発生するコギング トルクの次数成分をほほ正確に予測できると考えられる。 予測した成分の中には実際には発生しないものが含まれる 場合があるが, これについては歪の振幅やスロット開口部 幅などの条件により決定される。

\section{6. まとめ}

表面磁石形永久磁石モー夕（SPMSM）を対象に, 鉄心の 歪や磁気特性劣化などの製造誤差に起因して生じるコギン グトルクの発生条件を検討した。製造誤差としては固定子 側の因子を取り上げ，これを固定子パーミアンス分布の非 対称成分（固定子スロット数の整数倍以外の脈動成分）と して扱った。本論文の概要を以下にまとめる。

・モー夕空隙部の磁気エネルギー分布から出発して, 極 数次成分（1 回転あたり極数と同数ないしその整数倍 の脈動数を示す成分）のコギングトルクが固定子パー ミアンス分布の非対称成分に起因することを示した。 さらにパーミアンス非対称成分の空間次数とコギング トルク次数の関倸式を導いた。

- 極数/スロット数比が異なる三相モー夕の代表的な 7 
種の設計仕様に対し，パーミアンス非対称成分の空間 次数とコギングトルク次数の関係を具体的に示し，仕 様ごとの傾向の違いを論じた。例えば 8 極 12 スロッ トのモータでは 4 次や 8 次などの空間次数をもつ誤差 因子のみがコギングトルクの原因となる一方，8極 9 スロットのモータではほぼ全ての空間次数の誤差因子 が各々異なる脈動数のコギングトルクを引き起こす。

・導出した条件式の妥当性を検証するため, 7 種のモー 夕仕様に対し有限要素磁界解析を行った。固定子内径 の歪形状を種々変更し, 歪に起因するコギングトルク 発生の有無を調べた結果，上述の導出結果と良く一致 し，条件式の妥当性を確認できた。

本論文では固定子の内径歪を例に検討を行った。本稿で は詳細に触れないが，これまでに応力や磁気異方性などの製 造誤差因子により鉄心の磁気特性分布を不均一としたモー 夕を試験的に製作した。先の理論式に従って誤差因子の分 布を決定した結果，2次成分コギングトルクの発生を実機

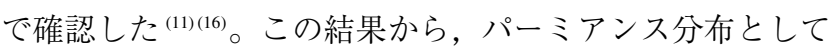
は内径歪に限定されることなく，鉄心の磁気特性分布に対 しても先の理論式が適用可能であると考えられる。

本稿では固定子側の製造誤差因子を主に取り上げた。回 転子側の製造誤差因子に起因する成分についても同様に条 件の導出が可能である。これについては稿を改めたい。

\section{(平成 17 年 11 月 25 日受付)}

\section{文献}

(1) 電気学会: 「小形モー夕の高性能化」, 電学技報, 744 (1999)

(2) H. Kometani: "The Modeling Technologies for Highly Accurate Electromagnetic Analyses of Rotating Machines", The Papers of Tech. Meeting on Rotating Machinery, IEE Japan, RM-05-120 (2005) (in Japanese) 米谷晴之:「回転機の高精度電磁界解析のためのモデリング技術」, 電 学回転機研資, RM-05-120 (2005)

（3）田中俊則：「電動パワーステアリング用モー夕」, 三菱電機技報, Vol.76, No.6, pp.387-390 (2002-6)

(4) M. Gotou and K. Kobayashi: "An Analysis of the Cogging Torque of a DC Motor and a New Reducing Technique", T. IEE Japan, Vol.103-B, No.11, pp.711-718 (1983-11) (in Japanese)

後藤 誠・小林一二:「直流モータのコギングトルクの解明と新し い低隇方法」, 電学論 B, Vol.103, No.11, pp.711-718 (1983-11)

(5) K. Ohnishi: "Cogging Torque Reduction in Permanent Magnet Brushless Motors", T. IEE Japan, Vol. 122, No.4, pp.338-345 (2002-4) (in Japanese) 大西和夫：「永久磁石ブラシレスモータのコギングトルク低減」, 電 学論 D, 122, 4, pp.338-345 (2002-4)

(6) N. Bianchi and S. Bolognani: "Design Techniques for Reducing the Cogging Torque in Surface-Mounted PM Motors", IEEE Trans. on IA, Vol.38, No.5, pp.1259-1265 (2002-5)

(7) A. Daikoku, N. Hashiguchi, N. Miyake, H. Ikejima, K. Inoue, M. Yasue, and T. Komatsu : "Development of Flat Type Permanent Magnet Motor For Machine-Room-Less Elevator", The Papers of Tech. Meeting on Rotating Machinery, IEE Japan, RM-01-113 (2001) (in Japanese) 大穀晃裕・ 橋口直樹· 三宅展明 - 池島宏行 · 井上健二 · 安江正徳 · 小松孝教:「機械室レス・エレベーター巻上機用永久磁石式薄形モー 夕の開発」, 電学回転機研資, RM-01-113 (2001)

(8) Y. Enomoto, M. Kitamura, T. Sakai, and K. Ohara: "Factor Analysis on Cogging Torque in Segment Core Motors", IEEJ Trans. IA, Vol.124, No.1, pp.85-90 (2004-1) (in Japanese)

榎本裕治・北村正司・酒井俊彦・大原光一郎：「分割コアモー夕のコ ギングトルク要因分析」, 電学論 D, 124, 1, pp.85-90 (2004-1)

(9) M.S. Islam, S. Mir, and T. Sebastian: "Issues in Reducing the Cogging Torque of Mass-Produced Permanent-Magnet Brushless DC Motor", IEEE Trans. on IA, Vol.40, No.3, pp.813-820 (2004-3)
(10) M. Natsumeda and H. Takabayashi: "The calculation method of cogging torque considered the variation of the magnet", 2004 National Convention Record, IEE Japan, No.5-094 (2004) (in Japanese)

賴田充俊・高林博文：「磁石の製造ばらつきを考慮したコギングト ルク推定法」, 平 16 年電学全大, No.5-094 (2004)

(11) A. Daikoku, S. Yamaguchi, Y. Toide, and T. Yoshioka: "Measurement of Cogging Torque Resulting from Non-oriented Steel's Magnetic Anisotropy in Permanent Magnet Motors", 2003 National Convention Record, IEE Japan, No.5-016 (2003-3) (in Japanese)

大款晃裕・山口信一・都出結花利・吉岡 孝:「無方向性電磁鋼板の 磁気異方性に起因する永久磁石モータのコギングトルクの測定」, 平 15 電学全大, No.5-016 (2003)

(12) S. Yamaguchi, A. Daikoku, and N. Takahashi: "Cogging torque calculation considering magnetic anisotropy for permanent magnet synchronous motors", COMPEL, Vol.23, No.3, pp.639-646 (2004)

13) A. Daikoku, M. Nakano, S. Yamaguchi, Y. Tani, Y. Toide, T. Yoshioka, H. Arita, and C. Fujino: "Cogging torque calculation considering stator core stress resulting from frame in permanent magnet motors", The Papers of Joint Tech. Meeting on Static Apparatus and Rotating Machinery, IEE Japan, SA-03-72, RM-03-74 (2003) (in Japanese)

大穀晃裕・中野正嗣・山口信一·谷良 浩 ·都出結花利 · 吉岡 孝· 有田秀哲・藤野千代：「フレームの応力の影響を考慮した PM モー タのコギングトルク解析」, 電学静止器・回転機合同研資, SA-03-72, RM-03-74 (2003)

(14) M. Nakano, A. Daikoku, S. Yamaguchi, Y. Tani, H. Arita, Y. Toide, T. Yoshioka, and C. Fujino: "Cogging Torque Calculation Considering Distribution of Principal Stress of Stator Core in Permanent Magnet Motors", The Papers of Joint Tech. Meeting on Static Apparatus and Rotating Machinery, IEE Japan, SA-04-16, RM-04-16 (2004) (in Japanese)

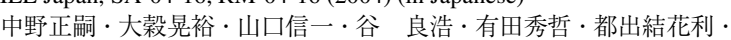
吉岡 孝・藤野千代：「固定子鉄心の主応力分布を考慮した PM モー タのコギングトルク解析」, 電学静止器・回転機合同研資, SA-04-16, RM-04-16 (2004)

（15） S.J. Yang, 斉藤文利訳：ロー・ノイズ・モー夕, 総合電子出版社 (1983)

(16) A. Daikoku, Y. Toide, T. Yoshioka, S. Yamaguchi, M. Nakano, H. Arita, Y. Tani, and C. Fujino: "Cogging Torque Examination in Permanent Magnet Motors with Stressed Stator Core", The Papers of Tech. Meeting on Rotating Machinery, IEE Japan, RM-03-152 (2003) (in Japanese)

大穀晃裕・都出結花利 · 吉岡 孝・ 山口信一 - 中野正嗣 - 有田秀哲 . 谷 良浩・藤野千代：「外部応力印加時の PM モータのコギングト ルクに関する実験検討」,電学回転機研資, RM-03-152 (2003)

大 款 晃 裕 (正員) 1965 年 11 月 8 日生。1 1989 年 3 月京都 大学工学部電気工学科卒業。1991 年 3 月京都大 学大学院工学研究科電気工学専攻博士課程前期修 了。同年 4 月三菱電機 (株) 入社。現在, 先端技術 総合研究所にて, モー夕, 発電機などの電磁機器 の高性能化に関する研究開発に従事。IEEE 会員。

中 野 正 嗣 (正員) 1972 年 9 月 25 日生。1996 年 3 月京都

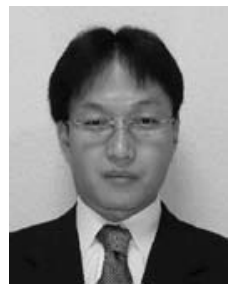
大学工学部電気工学第二学科卒業。1998 年 3 月 京都大学大学院工学研究科電気工学専攻修了。同 年 4 月三菱電機（株）入社。現在，先端技術総合 研究所にて, モー夕, 発電機などの電磁機器の高 性能化に関する研究開発に従事。2004 年，2005 年電気学会論文発表賞受賞。IEEE 会員。 
山 口 信 - (正員) 1974 年 11 月 19 日生。1997 年 3 月同志 社大学工学部電気工学科卒業。1999 年 3 月同志 社大学大学院工学研究科電気工学専攻博士課程前 期修了。同年 4 月三菱電機（株）入社。現在，先 端技術総合研究所にて，モー夕等の電磁機器の高 性能化に関する研究開発に従事。

都 出 結花利 (正員) 1983 年 3 月大阪大学理学部物理学科卒 業。1985 年 3 月大阪大学大学院工学研究科電磁 エネルギー工学専攻修了。同年 4 月三菱電機 (株) 入社。1998 年まで光磁気ディスク開発に従事。現 在，先端技術総合研究所にて，モータなどの電磁 機器の高性能化に関する研究開発に従事。
米 谷 晴 之（正員） 1964 年 3 月 3 日生。1 989 年 3 月京都大

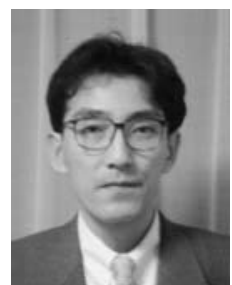
学大学院工学研究科電気工学専攻修了。同年 4 月 三菱電機（株）先端技術総合研究所入社。主とし て回転機, 電磁機器, 超電導機器の研究開発に従 事。1998 年電気学会論文発表賞 A 賞受賞。IEEE 会員。工学博士。

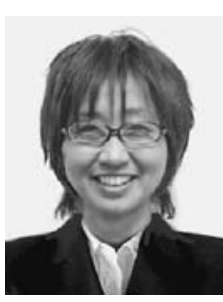

